世界の皮膚科学者 (117)

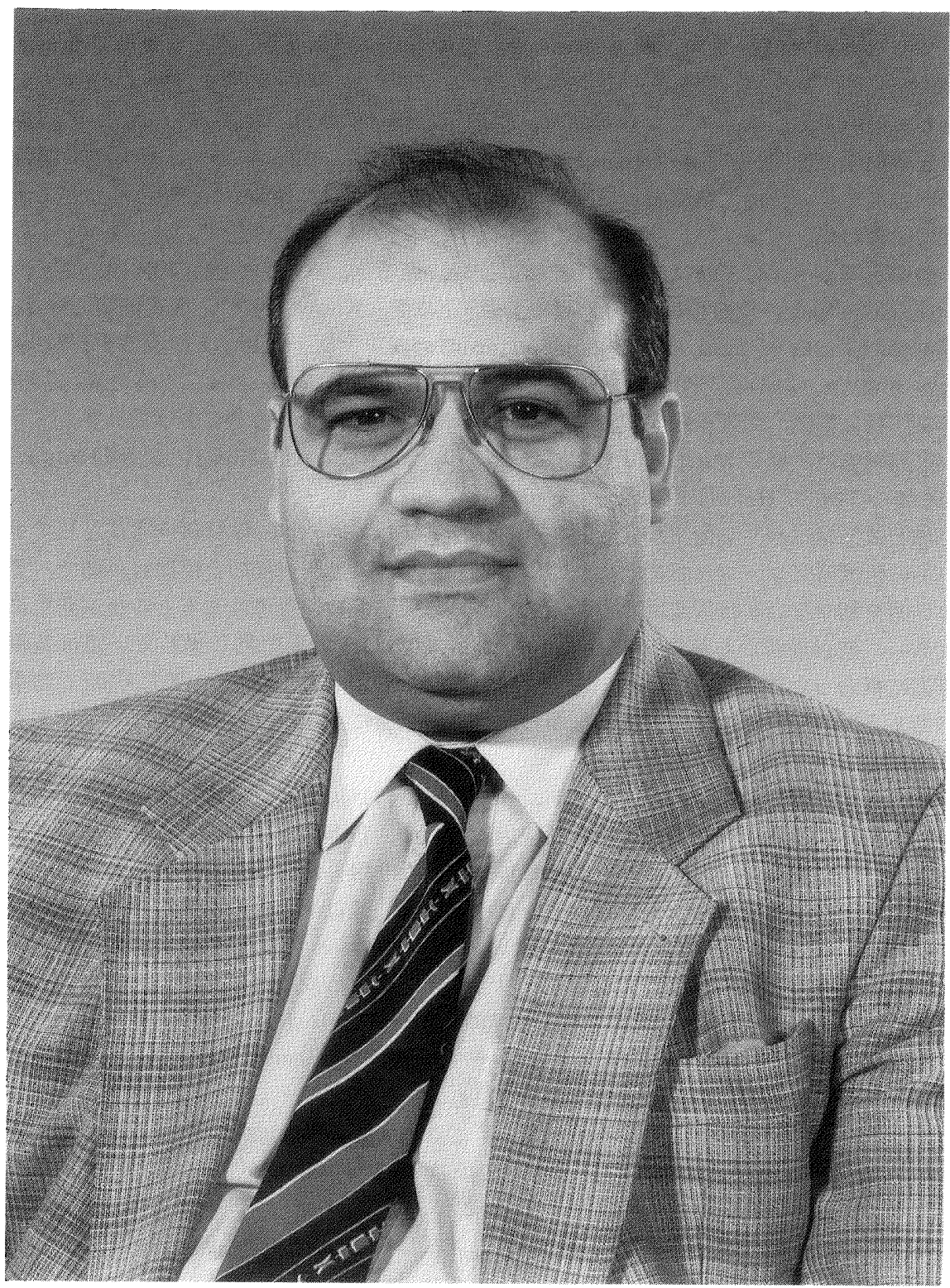

Augusto Jorge Mayer-da-Silva, M.D. 


\section{Augusto Jorge Mayer-da-Silva, M. D.}

Dr. Mayer-da-Silva は現在, ポルトガルのリスボン大学サンタマリア病院皮虐科助 教授として活躍している皮膚科医である。

1951 年 1 月 31 日, ポルトガルのカルタコで生まれ, アンゴラ, ポルトガルでホ・中・ 高校を終え, リスボン大学医学部を卒業した。1977 年, 細胞生物学の teaching stuff として研究をはじめ, その 1 年後から, 組織学と発生学の研究に従事したが, 1983 年 に皮庙科学に転向、“Aging of the skin”で学位を取得, 1985 年から 1988 年まで当時 の西独ベルリン自由大学皮虐科に留学, Orfanos 教授の下て research fellow として研 究に従事した。

彼の研究テーマは多岐にわたり, 皮成の加龄, 光老化, 真皮の細胞間基質の生物学, actinic elastosis, 皮腫黇(とりわけ血管系・上皮系, Kaposi 肉腫); 表皮細胞の分化, 薬剂(dicarboxylic acid, retinoid, interferon)の表皮ケラチノサイトに及ほす影響( in vivo and in vitro)などであるが, 何といっても彼のライフワークは“皮直の老化”で ある。特に電䫓, 免疫組織化学に造詣が㳭く, 極めて質の高い論文を出している。

家族構成は奥様の Maria Julieta と長女の Alexandra Maria(15 歳), 長男の Miguel (14 歳), 次女の Helena Maria(13 歳)の 5 人である。

私と彼とはベルリン留学が 2 年間オーバーラップしていたが，彼は研究室長としてす ベての研究のブレーンとして君臨していた。したがって, 研究室の公用語は英語で, ド イツ語を話せない私は大変助かった。私の英語の上達も彼の恩恵によるところが非常に 大きい。彼は最初から最後までOrfanos教授に抵抗して英語で押し通した。彼は基礎 研究に携わった期間が長いので, 研究に対する activity が大変高く, 頭脳明晰で物事 の考え方が論理的で合理的でありながら，既存の概念にとらわれない斬新な発想をする 人物である。

彼の趣味は絵, 音楽, 読書であるが, 私があえて付け加えるならば, 食べ歩きであろ う。ベルリンでは自国のポルトガル料理店をはじめ, 日本料理店などさまざまなレスト ランを一緒に食べ歩いた。おかげで彼は体重がかなり増えたようだ。また，お酒にも隇 法強く, 彼が酔っぱらった姿を見たことはなかった。彼はラテン系民族らしく大変陽気 で明るく, ジョークを愛し, 面倒見がよい。日本人の私ともお互いに非常に気心が知 れ, また, 彼の味覚には日本食がピッタリ合うようであった。昨年の 4 月, 岐阜で行わ れた日本皮膚科学会総会・学術大会に特別請演者として招かれ, “Aging of the skin” の興味深い講演をされた。非常にわかりやすい明瞙な conceptのすばらしい講演で あった。時を同じく, Orfanos 教授が来口され，朝田教授とともにベルリンの懐かしい 思い出を酒の有にして楽しい夕べを過ごした。また, 京都では金閣寺, 龍安寺, 嵐山を 訪れ，楽しい一日を過ごされた。日本の印象は well-organizeされた国という印象で あった。

今後，ポルトガル皮苚科学会の牽引車として彼に大きな期待が奇せられている。 兵庫県立塚口病院皮科 黒 川一 郎 